\title{
Acute gouty bursitis: report of 15 cases
}

\author{
JUAN J. CANOSO ${ }^{1}$ AND ROBERT A. YOOD ${ }^{2}$ \\ From the ${ }^{1}$ Rheumatology Section, Medical Service, Boston Veterans Administration Hospital, and the \\ ${ }^{2}$ Arthritis and Connective Tissue Disease Section, Department of Medicine, Boston City Hospital, and University \\ Hospital, Boston, Massachusetts, USA
}

SUMMARY Fifteen cases of acute gouty bursitis were seen among 136 crystal-proved cases of gout. Bursal aspirate yielded yellow or pink fluid in 10 , chalky white fluid in 1 , and a small amount of $\dot{\infty}^{\circ}$ bloody fluid in 4. Monosodium urate crystals were present in all. Bursal fluid leucocyte counts averaged $2.9 \times 10^{9} / 1$ compared with synovial fluid leucocyte counts that averaged $25 \cdot 5 \times 10^{9} / 1$ in cases of articular gout $(P<0 \cdot 05)$. Gouty, septic, and idiopathic (traumatic) bursitis share clinical features, and detailed bursal fluid analysis is crucial for diagnosis.

Bursitis is a known manifestation of gout (Hench, 1941), but little information is available on its clinical and bursal findings. The present report describes 15 such cases seen by the Rheumatology Section at the Boston Veterans Administration Hospital over a recent 4-year period.

\section{Materials and methods}

Only cases of proved gout of subcutaneous bursae were included in the study. All patients had monosodium urate (MSU) crystals in bursal aspirate detected by compensated polarising microscopy, and all fulfilled the preliminary American Rheumatism Association criteria for acute gout (Wallace et al., 1977). All patients were male, reflecting the hospital population. When possible, bursal fluid was analysed according to standard techniques for synovial fluid (Cohen et al., 1975). Chemical determinations were performed by automated methods. The clinical features, characteristics of bursal fluid, treatment, and outcome were reviewed and compared with 121 cases of acute gouty arthritis seen during the same time period. Statistical analysis was made by Student's $t$ test.

\section{Results}

All patients had physical evidence of acute inflammation at the site of the affected bursa (Table 1). The underlying joint was normal in 14 and had

Accepted for publication 19 September 1978

Correspondence to Juan J. Canoso, MD, Room 10D-93,

Boston Veterans Administration Hospital, 150 South Huntington Avenue, Boston, Massachusetts 02130, USA. evidence of synovitis in 1 . Five other patients had $\stackrel{\infty}{\oplus}$ concurrent synovitis in a distant joint. Four patients $\vec{\theta}$ had tophi. Three patients were febrile (all less than $38 \cdot 5^{\circ} \mathrm{C}$ ). Two patients had definite trauma, while in several others the possibility of trauma could not be excluded because of alcoholism. While 13 patients gave the history of 1 or more previous episodes of acute arthritis and 8 were thought to have gout, a definite diagnosis had previously been established in only 3. Serum urate levels were elevated in 6 and normal in 9. Renal function was normal in 8 , borderline in 5 , and abnormal in 2 . Therapy consisted of standard doses of indomethacin or colchicine. Recovery was uneventful in all except 1 patient, who had a recurrence that later responded to an intrabursal corticosteroid injection.

In 4 patients only a trace of bloody bursal fluid could be obtained. Intracellular MSU crystals were found in 1 and extracellular MSU crystals in the $\bigcirc$ other 3. In 1 other case the aspirated fluid was chalky white. In this case, as well as in 9 cases of olecranon bursitis and 1 case of prepatellar bursitis, detailed analysis of the fluid could be performed (Table 2). $\sigma$ Bacterial cultures were all negative. The mucin clot $N$ was good to poor, leucocyte count averaged $2 \cdot 9 \times$ N $10^{9} / 1$ (range $0 \cdot 65-6 \cdot 6 \times 10^{9} / 1$ ), polymorphonuclear 0 leucocytes averaged $34 \%$ (range 4-87\%), and intracellular MSU crystals were seen in all.

In 121 cases of acute gouty arthritis seen concurrently full synovial fluid analysis could be 0 performed in 77. In these the mean WBC count was $25.5 \times 10^{9} / 1 \quad$ (range $\left.0.1-152.4 \times 10^{9} / 1\right) \quad(\mathrm{P}<0.05 \stackrel{\overbrace{}}{\circ}$ when compared with acute gouty bursitis). The $\mathbb{\mathbb { D }}$ synovial fluid polymorphonuclear leucocytes aver- $\frac{}{\circ}$ aged $87 \%$ (range $1-100 \%$ ). When only those patients 
Table 1 Acute gouty bursitis: clinical and laboratory characteristics

\begin{tabular}{|c|c|c|c|c|c|c|c|}
\hline Patient & Age & Bursa & $\begin{array}{l}\text { Duration of } \\
\text { bursitis (days) }\end{array}$ & $\begin{array}{l}\text { Associated } \\
\text { synovitis }\end{array}$ & Previous attacks & Tophi & $\begin{array}{l}\text { Serum urate } \\
(m g / d l)\end{array}$ \\
\hline 1 & 51 & Prepatellar & 2 & Ankle & - & - & $8 \cdot 1$ \\
\hline 3 & 53 & Prepatellar & 2 & - & Recurrent podagra & - & $7 \cdot 3$ \\
\hline 4 & 62 & Prepatellar & 2 & Ankle & Episodic arthritis for 10 years & - & $8 \cdot 4$ \\
\hline 5 & 76 & Bunion & 8 & Ankle* & Podagra 1 year earlier & - & $11 \cdot 4$ \\
\hline 6 & 52 & Olecranon & 28 & - & Recurrent podagra for 4 years & - & $8 \cdot 1$ \\
\hline 8 & 60 & Olecranon & 3 & Elbow & Podagra 7 months earlier* & - & 6.4 \\
\hline 9 & 62 & Olecranon & 8 & - & $\begin{array}{l}\text { Recurrent knee arthritis for } \\
2 \text { years }\end{array}$ & - & $8 \cdot 2$ \\
\hline 10 & 61 & Olecranon & 30 & 一 & Inflamed instep 5 years earlier & - & $9 \cdot 3$ \\
\hline 11 & 60 & Prepatellar & 1 & 一 & Episodic arthritis for $1 \frac{1}{2}$ years & - & $8 \cdot 0$ \\
\hline 12 & 56 & Olecranon & 70 & - & - & + & $8 \cdot 9$ \\
\hline 13 & 70 & Olecranon & 2 & 一 & $\begin{array}{l}\text { Episodic arthritis for } 12 \text { years } \\
\text { treated as gout }\end{array}$ & + & $5 \cdot 8$ \\
\hline 14 & 66 & Olecranon & 2 & Wrist & Arthritis for $1 \frac{1}{2}$ years & + & $8 \cdot 7$ \\
\hline
\end{tabular}

*MSU crystals documented in aspirate. $1 \mathrm{mg} / \mathrm{dl}$ urate $\approx 0.06 \mathrm{mmol} / 1$. Normal in our laboratory for males $\leq 8.2 \mathrm{mg} / \mathrm{dl}(0.49 \mathrm{mmol} / \mathrm{l})$.

Table 2 Acute gouty bursitis: bursal fluid findings

\begin{tabular}{|c|c|c|c|c|c|c|c|c|}
\hline Patient & $\begin{array}{l}\text { Volume } \\
\mathrm{ml}\end{array}$ & Colour & Viscosity & Mucin clot & $\begin{array}{l}W B C \\
\left(\times 10^{9} / 1\right)\end{array}$ & $\% P M N$ & $\begin{array}{l}R B C \\
\left(\times 10^{9} / 1\right)\end{array}$ & $\begin{array}{l}\text { MSU } \\
\text { crystals }\end{array}$ \\
\hline $\begin{array}{r}1 \\
2 \\
3 \\
4 \\
5 \\
6 \\
7 \\
8 \\
9 \\
10 \\
11 \\
12 \\
13 \\
14 \\
15\end{array}$ & $\begin{array}{l}\text { Trace } \\
\text { Trace } \\
\text { Trace } \\
\text { Trace } \\
1 \\
10 \\
2 \\
3 \\
1 \\
5 \\
0.5 \\
2.5 \\
0.3 \\
10 \\
0.7\end{array}$ & $\begin{array}{l}\text { Bloody } \\
\text { Bloody } \\
\text { Bloody } \\
\text { Bloody } \\
\text { White } \\
\text { Yellow } \\
\text { Pink } \\
\text { Yellow } \\
\text { Yellow } \\
\text { Pink } \\
\text { Pink } \\
\text { Pink } \\
\text { Pink } \\
\text { Pink } \\
\text { Pink } \\
\text { with white } \\
\text { particles }\end{array}$ & $\begin{array}{l}\text { ND* } \\
\text { ND } \\
\text { ND } \\
\text { ND } \\
\text { Viscous } \\
\text { Low } \\
\text { Low } \\
\text { Low } \\
\text { Low } \\
\text { Low } \\
\text { Low } \\
\text { Low } \\
\text { ND } \\
\text { Low } \\
\text { Low }\end{array}$ & $\begin{array}{l}\text { ND } \\
\text { ND } \\
\text { ND } \\
\text { ND } \\
\text { Good } \\
\text { Poor } \\
\text { Poor } \\
\text { Fair } \\
\text { Poor } \\
\text { Fair } \\
\text { Poor } \\
\text { Poor } \\
\text { Fair } \\
\text { Poor } \\
\text { Fair }\end{array}$ & $\begin{array}{l}\text { ND } \\
\text { ND } \\
\text { ND } \\
\text { ND } \\
3 \cdot 15 \\
1 \cdot 0 \\
4 \cdot 65 \\
4 \cdot 9 \\
2 \cdot 6 \\
1 \cdot 25 \\
1 \cdot 2 \\
0 \cdot 65 \\
6 \cdot 6 \\
3 \cdot 8 \\
2 \cdot 15\end{array}$ & $\begin{array}{l}\text { ND } \\
\text { ND } \\
\text { ND } \\
\text { ND } \\
40 \\
56 \\
73 \\
87 \\
8 \\
4 \\
15 \\
15 \\
\text { ND } \\
10 \\
50\end{array}$ & $\begin{array}{c}\text { Many } \\
\text { Many } \\
\text { Many } \\
\text { Many } \\
8 \cdot 1 \\
0 \cdot 48 \\
\text { ND } \\
1 \cdot 4 \\
0 \cdot 2 \\
56 \cdot 8 \\
46 \cdot 05 \\
30 \cdot 4 \\
104 \cdot 5 \\
8 \cdot 1 \\
35 \cdot 15\end{array}$ & $\begin{array}{l}+t \\
+ \\
+ \\
+ \\
+t \\
+t \\
+t \\
+t \\
+t \\
+t \\
+t \\
+t \\
+t \\
+t \\
+t\end{array}$ \\
\hline
\end{tabular}

*ND=not done. $\dagger$ Intracellular urate crystals.

seen in the first 3 days of the attack were considered, the mean synovial fluid WBC count was $39 \cdot 2 \times 10^{9} / 1$, and the mean bursal fluid WBC count was $3.9 \times 10^{9} / 1$ $(\mathrm{P}<0 \cdot 05)$.

\section{Discussion}

Subcutaneous bursae develop in areas subject to pressure and frictional forces such as the tip of the elbow and in front of the knee. Tophaceous deposits have been described in bursal walls (Jaffee, 1972). As with rheumatoid nodules, they tend to be palpable in the free wall of the bursae rather than at the bottom, where the nodules of traumatic bursitis usually occur (Canoso, 1977). In addition, owing to the exposed nature of those bursae, effusions with spontaneous resolution in all probability occur in response to minor trauma. Thus, acute gouty subcutaneous bursitis might result from $(a)$ shedding of
MSU crystals into the bursal sac (McCarty, 1977), and $(b)$ transient increase in urate concentration during resorption of a traumatic effusion (Simkin, 1973).

An interesting feature of gouty bursal aspirates was the relatively low WBC and percentage of polymorphonuclear cells as compared with cases of articular gout. Other peculiarities of subcutaneous bursae have been described, such as the poor mucin clot in cases of traumatic bursitis (Canoso, 1977) and the fact that most cases of septic bursitis occur from direct penetration of skin bacteria rather than as a result of bacteraemia (Ho et al., 1978; Canoso and Sheckman, in press). Thus, the structural similarities of bursal and synovial membrane (Key, 1932; Bywaters, 1965; Becker and Rauterberg, 1970; Psaila and Mansel, 1978) may conceal important differences in their biological behaviour so far poorly understood. 
While gout was suspected on initial evaluation in most of our patients, exclusion of other common causes of acute bursitis such as trauma or sepsis was not possible on clinical grounds alone. Idiopathic (traumatic) bursitis may present with severe local inflammation resembling gout or infection (Canoso, 1977). Septic bursitis may present as an acute or subacute process usually without fever (Ho et al., 1978; Canoso and Sheckman, in press). In addition both septic and gouty bursitis may be precipitated by local trauma, and concurrent gouty and septic bursitis has been reported (Ho et al., 1978). Thus the importance of bursal aspiration with bursal fluid analysis cannot be overemphasised. As neither septic nor gouty bursal fluid need appear purulent, a low bursal fluid WBC or 'non-inflammatory' appearing fluid should not deter the clinician from performing compensated polarising microscopy, Gram stain, and culture.

The authors are indebted to Dr A. S. Cohen for helpful review of the manuscript.

\section{References}

Becker, W., and Rauterberg, K. (1970). Zur Mikromophologie auskleidender Gewebe der Bursa. Archiv für Orthopaedische und Unfall-Chirurgie, 68, 197-203.

Bywaters, E. G. L. (1965). The bursae of the body. Annals of the Rheumatic Diseases, 24, 215-218.
Canoso, J. J. (1977). Idiopathic or traumatic olecranono bursitis. Clinical features and bursal fluid analysis Arthritis and Rheumatism, 20, 1213-1216.

Canoso, J. J., and Sheckman, P. R. (in press). Septic sub=O cutaneous bursitis. Report of sixteen cases. Journal of Rheumatology.

Cohen, A. S., Brandt, K. D., and Krey, P. R. (1975). Synovial fluid. Laboratory Diagnostic Procedures in the Rheumatico Diseases, 2nd edition, pp. 1-62. Edited by A. S. Cohen.0ొ Little, Brown: Boston.

Hench, P. S. (1941). Diagnosis and treatment of gout and $\vec{O}$ gouty arthritis. Journal of the American Medical Association, 116, 453-459.

Ho, G., jun., Tice, A. D., and Kaplan, S. R. (1978). Septic bursitis in the prepatellar and olecranon bursae. An analysis of 25 cases. Annals of Internal Medicine, 89,

Jaffee, H. L. (1972). Metabolic, Degenerative and Inflam-i matory Diseases of Bones and Joints, p. 498. Lea and Febiger: Philadelphia.

Key, J. A. (1932). The synovial membrane of joints and음 bursae. Special Cytology, 2nd edn., vol. 2, pp. 1055-1076. Edited by E. V. Cowdry. Paul B. Hoeber: New York.

McCarty, D. J. (1977). The gouty toe-a multifactorial condition. Annals of Internal Medicine, 86, 234-236.

Psaila, J. V., and Mansel, R. E. (1978). The surface ultra- $\bar{\oplus}$ structure of ganglia. Journal of Bone and Joint Surgery, 60B, 228-233.

Simkin, P. A. (1973). Local concentration of urate in the pathogenesis of gout. Lancet, 2, 1295-1298.

Wallace, S. L., Robinson, H., Masi, A. T., Decker, J. L., McCarty, D. J., and Yu, T-F. (1977). Preliminary criteria for the classification of the acute arthritis of primaryō gout. Arthritis and Rheumatism, 20, 895-900. 